\title{
Environmental Regulation, Outward Foreign Direct Investment, and Low-Carbon Innovation: An Empirical Study Based on Provincial Spatial Panel Data in China
}

\author{
Chaojun Yang, ${ }^{1}$ Liju Liu $\mathbb{D}^{1},{ }^{1}$ Wenke Yang $\mathbb{D}^{2},{ }^{2}$ and Tanveer Ahmed ${ }^{1}$ \\ ${ }^{1}$ Faculty of Management and Economics, Kunming University of Science and Technology, Kunming, China \\ ${ }^{2}$ School of Economics and Management, Southeast University, Nanjing, China \\ Correspondence should be addressed to Liju Liu; 1908528396@qq.com and Wenke Yang; wenkedyang@gmail.com
}

Received 25 June 2021; Accepted 9 September 2021; Published 27 September 2021

Academic Editor: Yi Su

Copyright ( 92021 Chaojun Yang et al. This is an open access article distributed under the Creative Commons Attribution License, which permits unrestricted use, distribution, and reproduction in any medium, provided the original work is properly cited.

\begin{abstract}
The low-carbon transformation has turned out to be a challenging task faced by government agencies, enterprises, and society because of the global warming. Endorsing the expansion of the low-carbon revolution is considered as an essential measure for low-carbon alteration and advancement. Therefore, articulating realistic environmental control strategies intended to enhance the motivation level of low-carbon innovation, though outward foreign direct investment (OFDI) can produce direct and indirect influences on the growth of low-carbon innovation. According to the data of 30 provinces of China from 2004 to 2017 , the relationship among environmental regulation, OFDI, and low-carbon innovation was analyzed using the spatial econometric model. Based on the analyzed data, the following conclusions were drawn. (i) From the national and regional perspectives, China's low-carbon innovation takes understandable agglomeration features in the longitudinal dimension. In addition, environmental regulation plays a key role in promoting low-carbon innovation and regional heterogeneity. (ii) Environmental regulation might force enterprises outward foreign direct investment efficiently and increase the level of OFDI that will be capable of promoting low-carbon innovation. (iii) OFDI acts as an intermediary in the relationship between environmental regulation and low-carbon innovation, and this role has regional heterogeneity. (iv) There are significant spatial spillover effects of environmental regulation and OFDI on low-carbon innovation, environmental regulation on OFDI, and the intermediary effect of OFDI on environmental regulation and low-carbon innovation. This study supplements our understanding of the relationship between environmental regulation and OFDI, in addition to low-carbon innovation, which provides illumination for enterprise practice, as well as decision-makers.
\end{abstract}

\section{Introduction}

The most common issues such as global warming, energy shortage, and high emissions have been considered worldwide. In addition, $\mathrm{CO}_{2}$ emissions have become the core source of greenhouse outcomes, and environmental complications, in addition to global warming. Hence, vital steps, including instigating the low-carbon economy perception, adopting low-carbon technologies, and enlightening the efficacy of resource utilization along with decreasing $\mathrm{CO}_{2}$ emission, are considered to achieve sustainable economic and social development. Generally, environmental regulation depends on the government's authority, in addition to tangible official measures, imposing economic entities to decrease the pollution emissions, conforming to environmental rules and regulations, and creating a decent ecological atmosphere. Meanwhile, government directives have influenced strategies along with institutional barriers for defending local economic interests, making the situation more problematic to understand free flow with the optimum allocation of production features, leading to easy underestimation of factor values in addition to altering the factor market, and also confining healthy development of independent innovation ability [1]. Nevertheless, the environmental regulation has a "technological innovation effect" $[2,3]$. In particular, the positive effect of environmental regulation on investment may be declining along with an increase in environmental regulation [4, 5]. Moreover, 
alteration of the factor market probably changes the purpose of behavior as well as the motivation of enterprises of OFDI, and corresponding factors are rationally allocated to enterprises and departments with high innovation efficiency; thus, it is more valuable for OFDI to endorse technological innovation in a host country [6-8].

However, the frequent existence of clouded weather, ecological deterioration, and environmental pollution in China is progressively projecting. Specifically, low-carbon innovation is considered an essential powerful strength that is immediately required to change the outmoded extensive mode of economic growth along with high carbon emissions to promote ecological civilization construction, in addition to low-carbon development. The government of China has delivered a series of environmental regulation strategies to resolve environmental problems, improve energy efficiency, and improve environmental performance [9]. The relationship between environmental regulation and investment is concerned, which is principally divided into three main views. Firstly, environmental regulation can endorse investment $[10,11]$. The second view is that environmental regulation overwhelms investment [12]. Third, there is a nonlinear relationship between environmental regulation and corporate green investment $[12,13]$. Furthermore, the different types of environmental regulation are also considered important factors that account for the different results for low-carbon innovation. Environmental regulation has a strong and significant positive impact on technological innovation $[14,15]$.

China, considered as the world's second-largest economic country, has completed stable development in the opening-up strategy, and the level of OFDI has grown rapidly, standing decisively amongst the world's highest's ranking at the same time [16]. Still, technological advancement is contingent not only on $\mathrm{R} \& \mathrm{D}$ input, but also on the spillover of R\&D technology from other countries under economic globalization. Generally, OFDI is a crucial channel for R\&D technology spillover, in addition to the significant ways to partake in the international division of labor and international collaboration [17]. In addition, OFDI stabilizes and intensifies the market, in addition to accomplishing an important source of world capital. Developing markets to invest in advanced countries is a decisive means for multinational companies to obtain advanced technology knowledge [18]. Usually, enterprises with backward technology probably achieve technological innovation by accepting OFDI to acquire advanced technology in the host country $[19,20]$. In the meantime, enterprises can avoid international trade barriers and set up businesses to provide sufficient financial support for their independent $R \& D$ through OFDI, thereby promoting technological innovation and productivity improvement in their home countries, which makes low-carbon innovation planned goals possible [21-23].

In the location choice of OFDI, Kang and Jiang [24] grasp the opinion that Chinese companies tend to invest in countries or regions with relatively free economies that have a severe political system. In combination with related works, Ren and Yang [25] state that geographical distance, economic distance, informational distance, and institutional distance may have a significant effect on OFDI. As a matter of fact, the major reasons for Chinese OFDI are the great demand for natural resources and the high environmental pressure China is faced with. Specifically, emerging market enterprises upgrade innovation capabilities via OFDI. To put it differently, multinational corporations from China may accelerate organizational learning to acquire technologies using OFDI in the host market $[7,26]$.

Building upon the studies above, this study attempts to fill in the missing link. First, we donate the literature by considering the linkage between regional carbon innovation ability and spatial econometric model based on the panel data of 30 Chinese provinces from 2004 to 2017, which will empirically analyze the spatiotemporal evolutionary characteristics and then articulate reasonable environmental regulation policies to lead low-carbon innovation compared to the study of $\mathrm{Su}$ et al. [27]. Second, we make OFDI according to the regional development characteristics of China to introduce foreign advanced low-carbon technologies to reduce pollutant emissions and eventually achieve sustainable economic and social development. Third, we analyze the relationship among environmental regulation, OFDI, and low-carbon innovation to provide interesting understandings intended for numerous reasons: (i) whether the intensity of environmental regulations is similar to the large economic and geographical differences in China. Has heterogeneity affected the development of low-carbon innovation? (ii) Whether OFDI in China acts as an intermediary variable in the impact of environmental regulation on low-carbon innovation; that is, there is an intermediary effect. (iii) Does the intermediary effect exist or have regional heterogeneity in the east, center, and west of China?

The remainder of the paper is structured as follows: Section 2 comprises the literature review and the construction of the hypothesis. Section 3 presents the estimated results of the analyses. Finally, Section 4 presents a summary of our findings and implications for future work.

\section{Literature Review and Hypothesis Construction}

At present, the relationship between environmental regulation and OFDI in addition to low-carbon innovation is still in the process of exploration and has not been discussed in the same research framework. Consequently, we study the literature on the relationship between environmental regulations besides low-carbon innovation, OFDI, and planned research hypotheses.

\subsection{Environmental Regulations and Low-Carbon Innovation.} Current increases in carbon emissions cause global warming, affecting the quality of human life [28]. Therefore, numerous types of environmental strategies are generally used by the government to control environmental pollution and encourage enterprises to carry out low-carbon innovation [29]. The arrangement of environmental factors in production strategies is essential for enterprises [30]. 
Nonetheless, dissimilar types of environmental strategies may complement and even conflict with each other. Even with the same policies in different countries and regions, the effects may vary [31]. Generally, environmental policy can trigger the speed of low-carbon innovation development [32]. For one thing, the government issues environmental policies to promote low-carbon innovation and reduce $\mathrm{CO}_{2}$ emissions [33, 34]. In the UN Climate Summit, the British Prime Minister has declared that they will cut $\mathrm{CO}_{2}$ emissions by 80 percent by 2050 , which effectively supports the development of the low-carbon industry [35]. For another thing, several recent papers [36-38] support Porter's hypothesis. Porter's hypothesis advocates that designing scientific and appropriate environmental regulations can reassure companies to conduct technological innovation $[39,40]$. The benefits of such technological innovation can moderately offset or even exceed the costs of complying with environmental regulations, enhance resource allocation, and achieve a win-win economic and environmental situation. Therefore, we propose the following hypothesis.

Hypothesis 1. The environmental regulations are positively associated with low-carbon innovation.

2.2. OFDI and Low-Carbon Innovation. OFDI can recover $\mathrm{R} \& \mathrm{D}$ and innovation performance in emerging economies [7]. First, technological stragglers accomplish and develop advanced technologies over OFDI [41]. Perceiving, imitating, and reverse engineering are imperative methods for developing countries to learn and absorb new technologies and realize reinnovation [42-44]. For example, emerging economies learn new technology through strategic alliances such as subsidiaries and joint ventures to make up for the weak $\mathrm{R} \& \mathrm{D}$ resources amid intense global competition [45-47]. Thus, OFDI such as establishing R\&D institutions in the United States is likely to obtain reverse technology spillovers to improve innovation [48]. In addition, OFDI has the potential to acquire a crucial part of technologies by purchasing and achieving licenses from the open market and then disassemble products into visible and lower technological components. The most typical example is that the Chinese BOE Technology Group acquired TFT-LCD technologies in South Korea.

Over the past thirty years, OFDI has played an essential role in China's economic and innovation development [45]. On the one hand, OFDI is highly positively related to China's domestic economic development [46]. However, the performance of OFDI in different stages of economic development is divergent. For instance, developed countries are likely to seek "pollution haven or shelter," while developing countries are targeting acquiring advanced technologies [47-49]. On the other hand, the World Investment Report (WIR) provides evidence that OFDI accelerates the speed of globalization of innovation. However, simple innovation no longer meets the basic requirement of the strategic goal of sustainable development, and low-carbon innovation is increasingly important in global races [28]. Hence, we may advance the following hypothesis:
Hypothesis 2. The effect of OFDI on low-carbon innovation is stronger for developed economies than for developing economies.

2.3. Environmental Regulations, OFDI, and Low-Carbon Innovation. Along with the deterioration of the world environment, governments around the world continue to strengthen their environmental directives to numerous degrees. Environmental regulation is becoming a significant feature that affects a firm's investment decisions and financial performance [50]. The tolerance of environmental regulation is a possible resource for comparative advantage in foreign direct investment. Infecting industries that will migrate from countries with stringent environmental regulation to countries with relaxed environmental regulations. Green barriers such as environmental regulations have affected investment by foreign companies in China. Green innovation technologies carried by foreign investment will also have positive effects on the host country's environment [51]. Furthermore, environmental regulation policies and institutional barriers have distorted factor markets and would change the investment behavior and motivation of foreign enterprises. As soon as environmental regulation assigns factors to enterprises besides departments with high innovation proficiency, it is conducive to the promotion effect of OFDI on the technological innovation of Chinese [6]. Nevertheless, there is no evidence of whether environmental regulation has an indirect impact on low-carbon innovation through the reverse space technology spillover of OFDI after sorting out literature. Thus, we hypothesize the following:

Hypothesis 3. Environmental regulation has an indirect impact on low-carbon innovation through the spillover effect of OFDI's reverse space technology.

The theoretical framework comprises the relationship between environmental regulation, OFDI, and low-carbon innovation (Figure 1).

\section{Materials and Methods}

3.1. Sample and Data. In 2013, the classification system of CPC-Y02 moderation climate change technology or application patent jointly issued by EPO along with USPTO has the characteristics of systematization and structure, which is suitable for tracking and studying the overall innovation trend of low-carbon technology. Numerous scholars have used this system to study low-carbon technology innovation and related issues $[52,53]$. Therefore, in this study, INCOPAT patent retrieval system is used as the platform for patent retrieval, and low-carbon patent application data as an indicator of low-carbon innovation in the manufacturing industry. Due to the lack of data in Tibet, Hong Kong, Macao, and Taiwan, it was deleted, and the relevant data of 30 provinces in China from 2004 to 2017 were taken as the sample of research. After inputting the CPC classification number and searching by Y02 (Note that, according to different regions and years, we input 


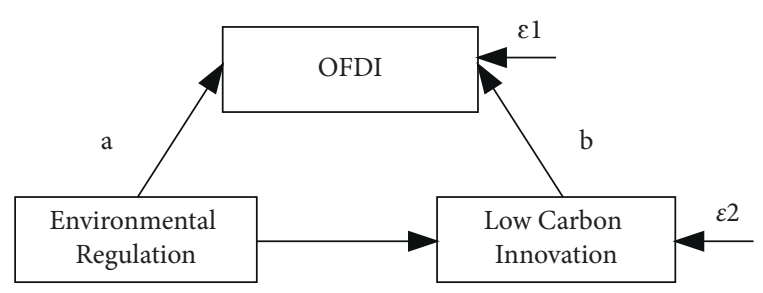

FIgURE 1: Theoretical Framework for the impact of environmental regulation, OFDI, and low-carbon innovation.

search terms in application number, public or announcement date, and CPC search fields, then get the lowcarbon patent application situation of low-carbon technology in a certain region and a certain year, and then evaluate the current situation of foreign patent application and layout of low-carbon technology in China.), we can view the patent summary combined with the definition of low-carbon technology products for screening. Further data mainly come from the China Statistical Yearbook, China OFDI Statistical Bulletin, China Foreign Trade and Economic Statistics Yearbook, and so forth.

\subsection{Variables}

3.2.1. Explained Variables. Low-carbon innovation is a necessary condition to change the current situation of resource and environmental constraints and realize environmental load reduction. Compared with traditional technological innovation, low-carbon innovation has more external positive effects that can bring more social benefits to enterprises. According to the existing literature on innovation measurement, the number of low-carbon innovation patent applications is selected to measure low-carbon innovation output $[52,53]$.

3.2.2. Explanatory Variables. Environmental regulation is a measure taken by the government to limit the pollution of enterprises to deal with the externalities of environmental problems. Nonetheless, China's policies and measures for environmental regulation are more diversified, the relevant data are difficult to obtain, and the data quality is comparatively weak. However, local governments, the implementing body of environmental regulation, have gigantic control over resources and become powerful [54]. As a consequence, local governments have strategic interaction and appear "race to the bottom," decreasing environmental supervision standards at the cost of the environment [55]. Much worse, "diversified competition" between governments may happen, because some governments are likely to strengthen or loosen environmental regulation intensity, while others do not [54]. Meanwhile, governments, to attract resources, may compete to increase the environmental regulation intensity, which is called the government "race to the top" [56]. Nevertheless, rational environmental regulations effectively suppress $\mathrm{CO}_{2}$ emissions [57]. In addition, governance cost constrains free-riding behavior and can more directly transmit changes in government environmental regulation $[58,59]$. More importantly, the marginal cost benefits the measurement of the spillover effect from neighboring provincial regions [54]. In this study, the cost of environmental governance was used to measure the intensity of environmental regulations [60].

3.2.3. Mediating Variables. OFDI is a significant channel for learning and introducing foreign advanced technology and an important driving force in promoting the economic growth of China. The formulation of environmental rules not only will solve environmental problems, but also will affect the important factors of FDI. Thus, the relationship between environmental regulations and OFDI is a key step in China's sustainable development and also plays an important role in China's development of low-carbon innovation. In this study, OFDI openness (OFDI/GDP) is the most direct indicator of OFDI.

3.2.4. Control Variables. This research paper comprises the following main indicators:

(1) Industrial structure (ES): As the tertiary industry accounts for a large proportion of GDP, the tertiary industry's development level can objectively reflect the optimization degree of regional economic structure, and the proportion of the added value of the tertiary industry in GDP can reflect the impact of industrial structure on low-carbon innovation output.

(2) International Trade (IP, EP): Under the standard market competition environment, the competition effect, learning effect, and other positive mechanisms of international trade can effectively promote the development of innovation. The impact of international trade on low-carbon innovation is expressed by IP (regional import/GDP) and EP (regional export/GDP).

(3) Foreign Direct Investment (FDI): The more open the country or region is, the more it can promote the flow of resources and the sharing of information technology and help the spillover and diffusion of external technology, thereby improving innovation level. FDI openness (FDI/GDP) is used to reflect the impact of technology spillovers on the host country's absorption and secondary innovation.

3.3. Model Specification. Environmental regulation is considered a national or local government's formulation of environmental pollution-associated laws and regulations to coordinate the harmonious development of the ecological environment and economy. However, China's current basic national conditions determine the imbalance between economic and social development. In that case, relevant policies and regulations of environmental regulation are difficult to improve, and the impact of environmental regulation on OFDI and low-carbon innovation has gradually 
become a new focus of social attention. Hence, we follow $\mathrm{Su}$ et al. [61] and adopt the following basic model:

$$
\begin{aligned}
\mathrm{LCI}_{i t}= & \beta_{0}+\beta_{1} \mathrm{ER}_{i t}+\beta_{2} \mathrm{ES}_{i t}+\beta_{3} \mathrm{IP}_{i t} \\
& +\beta_{4} \mathrm{EP}_{i t}+\beta_{5} \mathrm{FDI}_{i t}+\varepsilon_{i t}, \\
\mathrm{OFDI}_{i t}= & \beta_{0}+\beta_{1} \mathrm{ER}_{i t}+\varepsilon_{i t}, \\
\mathrm{LCI}_{i t}= & \beta_{0}+\beta_{1} \mathrm{ER}_{i t}+\beta_{2} \mathrm{ES}_{i t}+\beta_{3} \mathrm{OFDI}_{i t}+\beta_{4} \mathrm{IP}_{i t} \\
& +\beta_{5} \mathrm{EP}_{i t}+\beta_{6} \mathrm{FDI}_{i t}+\varepsilon_{i t} .
\end{aligned}
$$

Among them, $\mathrm{LCI}_{i t}$ captures the low-carbon innovation index, $\mathrm{ER}_{i t}$ is an environmental regulation index, $\mathrm{ES}_{i t}$ represents industrial structure, $\mathrm{IP}_{i t}$ expresses import index, $\mathrm{EP}_{i t}$ depicts export index, $\mathrm{FDI}_{\mathrm{it}}$ represents foreign direct investment index, OFDI ${ }_{\text {it }}$ represents OFDI index, $\beta_{0}$ describes intercept item, $\beta_{i}(i=1,2,3,4,5,6)$ represents estimation coefficient, $i$ represents the province, $t$ is time (2004-2017), $\varepsilon$ is the error term, and the index data have been processed in a dimensionless way.

\section{Results}

4.1. Autocorrelation Test of China's Low-Carbon Innovation Spatial. To judge the spatial characteristics of low-carbon innovation in different time nodes in 2004-2017, this study selects the data of 2005, 2009, 2013, and 2017 as the four nodes, selects the binary-based rook neighborhood weights to analyze the spatial correlation of China's low-carbon innovation capacity, and obtains the spatial geographic weight matrix. The spatial autocorrelation test of low-carbon innovation includes global autocorrelation and local spatial autocorrelation tests. To describe the spatial distribution of regional low-carbon innovation output from the perspective of China's overall regional space, and further explore the intermediary effect relationship among China's overall environmental regulation, OFDI, and low-carbon innovation output, Moran's I index, which mainly analyzes the overall spatial autocorrelation, is selected and calculated as follows:

$$
\text { Moran's } I=\frac{\sum_{i=1}^{n} \sum_{j=1}^{n} W_{i j}\left(Y_{i}-\bar{Y}\right)\left(Y_{j}-\bar{Y}\right)}{S^{2} \sum_{i=1}^{n} \sum_{j=1}^{n} W_{i j}},
$$

where $\bar{Y}=(1 / n) \sum_{i=1}^{n} Y_{i}, S^{2}=(1 / n) \sum_{i}\left(Y_{i}-\bar{Y}\right)^{2}, Y_{i}$ is the observation value of area $I, n$ is the total number of regions, and $W_{i j}$ is the space weight coefficient matrix. The $I$ value is usually $-1 \leq I \leq 1$. When $I>0$, the behavior among regions has a positive spatial correlation, and the size is proportional to the $I$ value; when $I<0$, the behavior of each region has negative spatial correlation and discrete distribution; $I=0$ indicates that the behavior of each region is randomly distributed.

Moran's I indexes of the four-time nodes of China's lowcarbon innovation output are all positive, and the significance results are $0.022,0.046,0.016$, and 0.024 , respectively, which means that, in 2005, 2009, 2013, and 2017, the significance of the normal distribution has passed the water level test of $5 \%$ significance. Because the $Z$ value is greater than the critical value 1.6 of the normal distribution function at $5 \%$ level, it shows that China's low-carbon innovation has a significant positive correlation in the spatial distribution in 2010 and 2015, and similar characteristic values of lowcarbon innovation in adjacent regions of provinces and regions in China show a trend of clustering (see Table 1).

4.2. Local Spatial Autocorrelation Test of Low-Carbon Innovation. To measure the spatial difference of low-carbon innovation output in the eastern, central, and western regions of China, and facilitate the analysis of the intermediary effect relationship among regional environmental regulation, outward foreign direct investment, and low-carbon innovation output, Moran scatter diagrams and Lisa cluster diagrams were selected for measurement. The formula for calculating the local Moran's I index is as follows:

$$
I_{i}=\frac{Y_{i}-Y}{S^{2}}=\sum_{j=1}^{n} W_{i j}\left(Y_{j}-\bar{Y}\right) \text {. }
$$

$I>0$ indicates that there is a strong positive spatial autocorrelation between the observation value of area I and the adjacent area, showing spatial agglomeration. When $I<0$, it has a strong negative spatial autocorrelation with the adjacent area; it is spatially discrete. Because the global Moran's $I$ index makes it difficult to measure the local spatial autocorrelation and spatial cluster trend characteristics of lowcarbon innovation in the province, the local indicator cluster analysis method is selected, and the GeoDa software generates the local Moran's scatter map to observe the local spatial characteristics of low-carbon innovation.

Among the four-time nodes in 2005, 2009, 2013, and 2017, provinces accounted for the largest proportion in the first and third quadrants, rejecting the original assumption that low-carbon innovation output was not randomly distributed in space, and there was a positive correlation effect in geospatial. Higher or lower low-carbon innovation provinces tended to be close to provinces with similar characteristics, meeting the global spatial autocorrelation test results. The corresponding quadrant positions of each province for the four-time nodes in 2005, 2009, 2013, and 2017 are shown in Figure 2. Most provinces and regions maintain time and space stability under the time node, Jiangsu, Zhejiang, Shanghai, Shandong, and other provinces and regions maintain the first quadrant $(\mathrm{H}-\mathrm{H})$ agglomeration, and Heilongjiang, Xinjiang, Shanxi, Ningxia, Gansu, Jilin, Qinghai, Inner Mongolia, and other provinces and regions maintain the third quadrant (L-L) agglomeration (Table 2).

To study the similar characteristics of China's higher or lower low-carbon innovation neighboring provinces, we drew the Lisa spatial agglomeration map. As shown in Table 2, the centers of the low-carbon innovation L-L cluster are Xinjiang, Qinghai, Gansu, Sichuan, and Shaanxi in 2005. Meanwhile, the center of the $\mathrm{H}-\mathrm{H}$ cluster is Jiangsu Province. Additionally, the center of the $\mathrm{H}-\mathrm{H}$ cluster is Jiangsu Province, and the centers of the L-L cluster are Xinjiang, Qinghai, Gansu, Sichuan, and Shaanxi Provinces in 2009. In 
TABle 1: Moran's I index of China's low-carbon innovation in 2005, 2009, 2013, and 2017.

\begin{tabular}{cccccc}
\hline Year & Moran's $I$ & Mean & S.E & $Z$ value & Probability \\
\hline 2005 & 0.241 & -0.032 & 0.110 & 2.476 & 2.061 \\
2009 & 0.194 & -0.033 & 0.110 & 2.618 & 0.046 \\
2013 & 0.234 & -0.034 & 0.106 & 2.242 & 0.016 \\
2017 & 0.209 & -0.035 & 0.109 & 0.024 \\
\hline
\end{tabular}
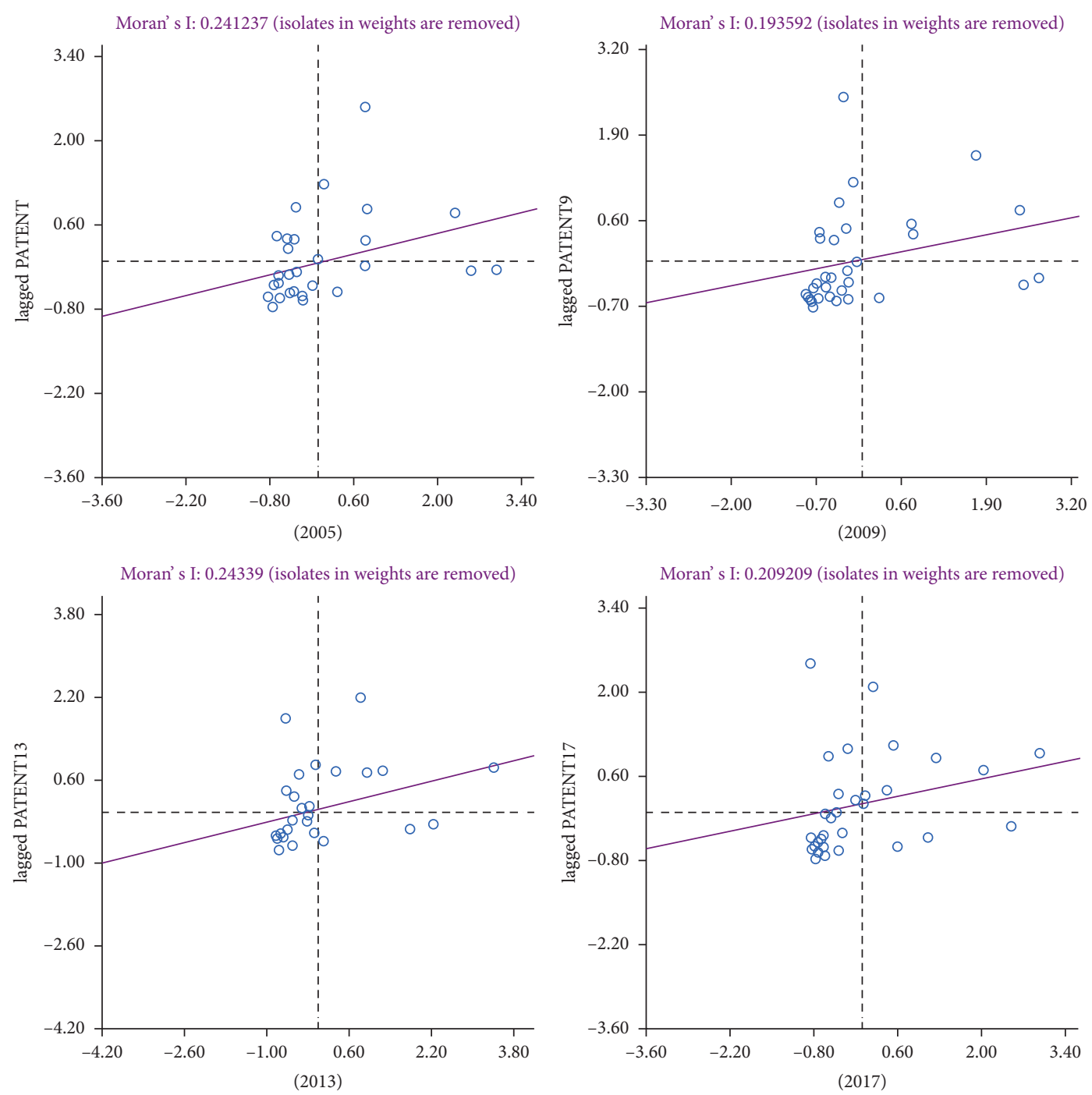

FIGURE 2: Moran's scatter diagram of low-carbon innovation in China.

addition, the center of the $\mathrm{H}-\mathrm{H}$ cluster is also Anhui Province, Jiangsu Province, and the center of the L-L cluster was Xinjiang, Inner Mongolia, and the $\mathrm{H}-\mathrm{L}$ cluster heart was Sichuan Province in 2013. Moreover, the center of the $\mathrm{H}-\mathrm{H}$ cluster was also Anhui Province, Jiangsu Province, Shandong Province, and Zhejiang Province, while the center of the L-L cluster was Xinjiang and Inner Mongolia, the center of the H-L cluster was Sichuan Province, and the center of L-H cluster is Jiangxi and Fujian Province in 2017 (see Figure 3). According to the results above, we can see that China's low-carbon innovation has obvious spatial agglomeration characteristics. Based on this, this study examines whether there are intermediary effects among environmental regulation, OFDI, and low-carbon innovation in the spatial dimension and uses the spatial econometric model for analysis.

4.3. Spatial Econometric Model Estimation. During 2004-2017, under the influence of early accession to the WTO, driven by economic globalization and the active implementation of the "going out strategy," the degree of regional economic integration continued to strengthen, and more and more enterprises went abroad to allocate resources and expand markets. Because of the feasibility of controlling variable data, this study excludes Guangdong, Hong Kong, 
TABLE 2: Moran spatial distribution of low-carbon innovation in China in 2005, 2009, 2013, and 2017.

\begin{tabular}{|c|c|c|c|c|c|}
\hline Time & First quadrant $(\mathrm{H}-\mathrm{H})$ & Second quadrant (H-L) & Third quadrant (L-L) & $\begin{array}{l}\text { Fourth quadrant } \\
(\mathrm{L}-\mathrm{H})\end{array}$ & Transfrontier state \\
\hline 2005 & $\begin{array}{l}\text { Jiangsu, Zhejiang, } \\
\text { Tianjin, Shanghai, } \\
\text { Hong Kong }\end{array}$ & $\begin{array}{c}\text { Fujian, Guangxi, Jiangxi, } \\
\text { Hebei, Anhui }\end{array}$ & $\begin{array}{l}\text { Heilongjiang, Xinjiang, Shanxi, } \\
\text { Ningxia, Tibet, Henan, Hubei, } \\
\text { Yunnan, Guizhou, Jilin, Qinghai, } \\
\text { Gansu, Shaanxi, Inner Mongolia, } \\
\text { Chongqing, Sichuan }\end{array}$ & $\begin{array}{c}\text { Shandong, } \\
\text { Guangdong, } \\
\text { Liaoning, Beijing }\end{array}$ & Hunan \\
\hline 2009 & $\begin{array}{l}\text { Shandong, Jiangsu, } \\
\text { Zhejiang, Shanghai }\end{array}$ & $\begin{array}{l}\text { Anhui, Jiangxi, Fujian, } \\
\text { Guangxi, Tianjin, Hebei, } \\
\text { Hong Kong }\end{array}$ & $\begin{array}{l}\text { Heilongjiang, Xinjiang, Shanxi, } \\
\text { Ningxia, Tibet, Henan, Hubei, } \\
\text { Yunnan, Guizhou, Jilin, Qinghai, } \\
\text { Gansu, Shaanxi, Inner Mongolia, } \\
\text { Chongqing, Sichuan }\end{array}$ & $\begin{array}{l}\text { Beijing, Liaoning, } \\
\text { Guangdong }\end{array}$ & Hunan \\
\hline 2013 & $\begin{array}{l}\text { Shandong, Jiangsu, } \\
\text { Anhui, Zhejiang, } \\
\text { Shanghai }\end{array}$ & $\begin{array}{l}\text { Henan, Jiangxi, Fujian, } \\
\text { Guangxi, Tianjin, Hebei, } \\
\text { Hong Kong }\end{array}$ & $\begin{array}{l}\text { Heilongjiang, Xinjiang, Shanxi, } \\
\text { Ningxia, Tibet, Hubei, Hunan, } \\
\text { Yunnan, Guizhou, Jilin, Qinghai, } \\
\text { Gansu, Shaanxi, Inner Mongolia, } \\
\text { Chongqing }\end{array}$ & $\begin{array}{l}\text { Guangdong, } \\
\text { Liaoning, Beijing, } \\
\text { Sichuan }\end{array}$ & \\
\hline 2017 & $\begin{array}{l}\text { Shandong, Jiangsu, } \\
\text { Anhui, Hubei, } \\
\text { Zhejiang, Hunan, } \\
\text { Guangxi, Shanghai }\end{array}$ & $\begin{array}{l}\text { Henan, Jiangxi, Fujian, } \\
\text { Tianjin, Hong Kong }\end{array}$ & $\begin{array}{l}\text { Heilongjiang, Xinjiang, Shanxi, } \\
\text { Ningxia, Tibet, Yunnan, Jilin, } \\
\text { Liaoning, Qinghai, Gansu, Shaanxi, } \\
\text { Inner Mongolia, Hebei }\end{array}$ & $\begin{array}{c}\text { Guangdong, } \\
\text { Beijing, Sichuan }\end{array}$ & $\begin{array}{l}\text { Guizhou, } \\
\text { Chongqing }\end{array}$ \\
\hline
\end{tabular}

Macao, and Tibet from spatial econometric analysis, divides 30 provinces and regions of low-carbon innovation in China, analyzes the basic spatial econometric model, selects corresponding variables, and combines Hausman test. The results show that the time fixed effect spatial model should be selected for all the models.

It can be seen from the LM Test in Table 3 that, for model 1, LMerr (23.490) and robust LMerr (15.180) are significant at the $1 \%$ level, and LMlag (18.694) and robust LMlag (10.383) are significant at the $1 \%$ level. In model 2, LMerr (42.572) and LMlag (41.527) are significant at the level of $1 \%$, while robust LMlag (3.128) and robust LMerr (4.173) are significant at $10 \%$ and 5\% levels, respectively. For model 3, LMerr (19.371) and robust LMerr (10.868) were significant at the level of 1\%, and LMlag (23.700) and robust LMlag (15.197) are significant at the level of $1 \%$ (Table 3). A spatial error model (SEM) was selected for spatial econometric analysis.

All estimates included the control variables. According to equation (1), from the national level, as well as the eastern and central regions, environmental regulation affects lowcarbon innovation at a significant level of $1 \%$. Western environmental regulation has no significant role in promoting low-carbon innovation, which verifies H1. This result shows that the enhancement of environmental regulation will promote the development of low-carbon innovation, and there is regional heterogeneity in the impact of environmental regulation on low-carbon innovation. According to equation (2), at the national and regional levels, environmental regulation affects OFDI at a significant level of $1 \%$, which indicates that when the intensity of environmental regulation increases, enterprises will introduce advanced technology from developed countries through OFDI, improve production efficiency and reduce costs, promote the improvement of the low-carbon innovation ability of enterprises, and verify $\mathrm{H} 2$. According to equation
(3), for the whole country, the eastern and the western regions, OFDI promotes the development of low-carbon innovation at the significant level of $1 \%$ and $5 \%$, which has no significant promotion effect in the central region, which verifies H3. It shows that the reverse technology spillover of OFDI will promote the low-carbon innovation capability of the host country. According to equation (4), for China as a whole and the eastern, central, and western regions, environmental regulation significantly promotes the development of low-carbon innovation at the $1 \%$ significance level and OFDI at the $1 \%$ and 5\% significant levels (see Table 4). The stricter the environmental regulation is, the more the OFDI increases significantly, and the output of low-carbon innovation also increases significantly. The three conditions that meet the intermediary effect are that China's overall and regional environmental regulation policies will directly introduce foreign advanced technology through the channels of OFDI, and reverse technology spillover of OFDI will accelerate the development of low-carbon innovation; that is, there is an intermediary effect, supporting $\mathrm{H} 4$.

\section{Test of Robustness}

To ensure the reliability of the empirical results, this study tests the robustness of the following two aspects from a national perspective. Firstly, it is the reevaluation of the replacement of the interpreted variable. Antweiler et al. [62] used GDP per capita as an alternative indicator of environmental regulation and concluded that, with rising income levels, environmental regulation is more stringent. Taking GDP per capita as an alternative index, this study makes a robustness test to examine its relationship with environmental regulation and OFDI. Second, for the reestimation of the replacement regression method, Anselin et al. [63] used SDM as the most robust analysis model and used the SDM model to test the robustness of the 


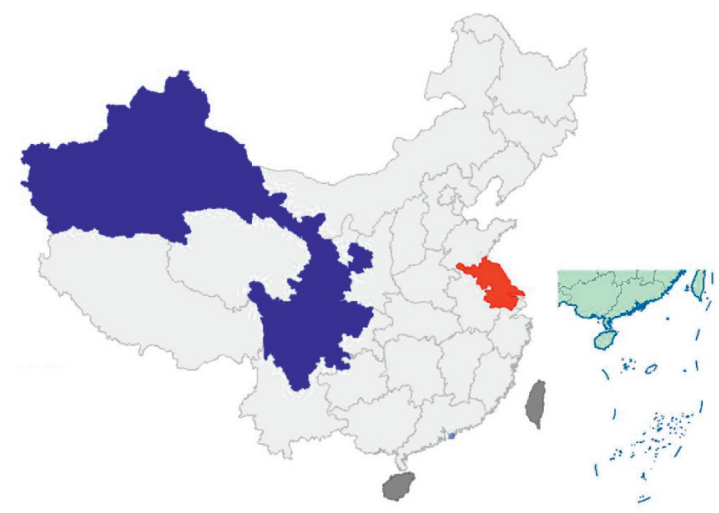

(2005)

LISA Cluster Map: sjxzq, I_LCI05
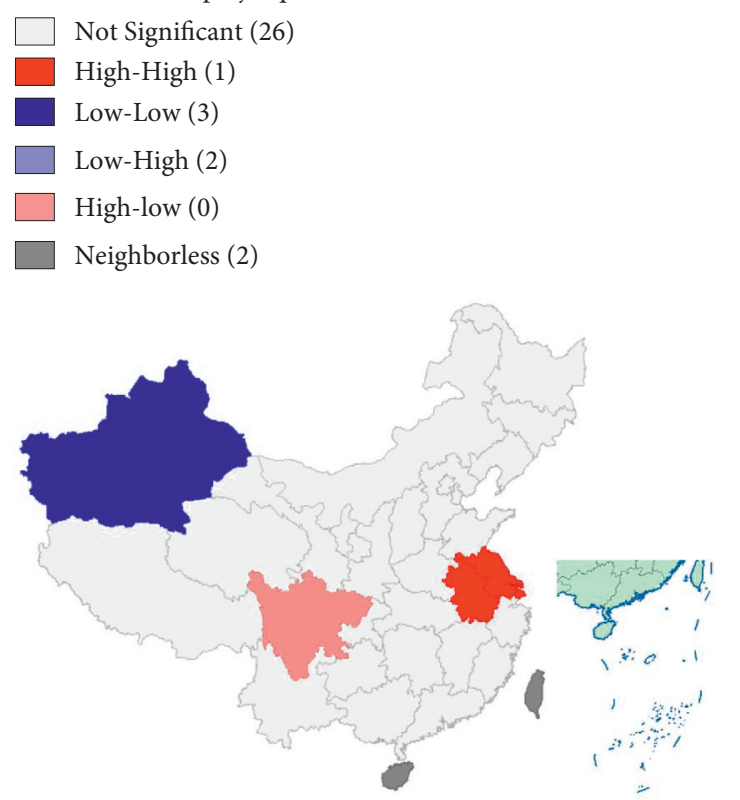

(2013)

LISA Cluster Map: sjxzq, I_LCI09

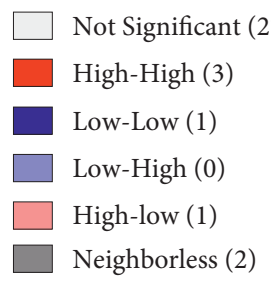

Figure 3: Low carbon innovation Lisa cluster in 2005, 2009, 2013, and 2017.

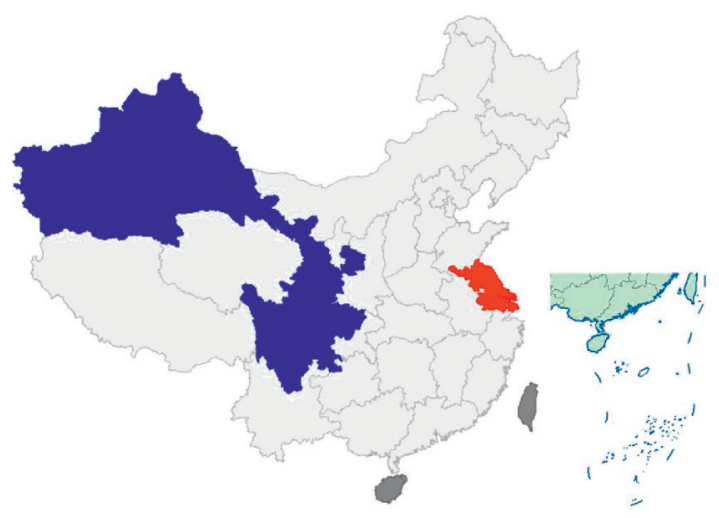

(2009)

LISA Cluster Map: sjxzq, I_LCI09
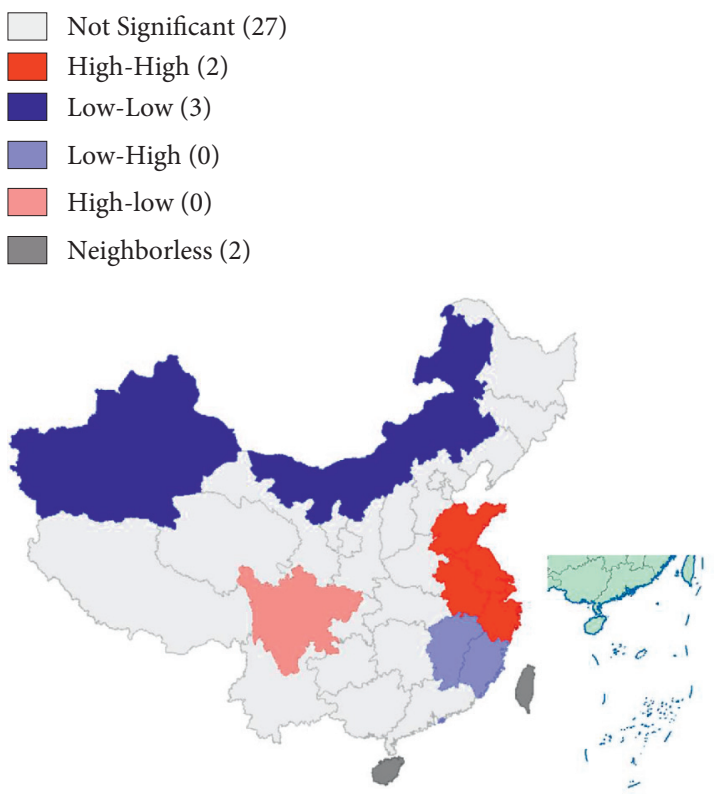

(2017)

LISA Cluster Map: sjxzq, I_LCI17

$\square$ Not Significant (20)

High-High (5)

Low-Low (2)

Low-High (4)

High-low (1)

Neighborless (2)

TABle 3: LM inspection table.

\begin{tabular}{|c|c|c|c|c|c|c|}
\hline & \multicolumn{2}{|c|}{ (1) } & \multicolumn{2}{|c|}{ (2) } & \multicolumn{2}{|c|}{ (3) } \\
\hline & Statistics & $P$ value & Statistics & $P$-value & Statistics & $P$-value \\
\hline Lagrange Multiplier (lag) & 18.694 & $\leq 0.001$ & 41.527 & $\leq 0.001$ & 23.700 & $\leq 0.001$ \\
\hline Robust LM (lag) & 10.383 & $\leq 0.001$ & 3.128 & $\leq 0.010$ & 15.197 & $\leq 0.001$ \\
\hline Lagrange Multiplier (error) & 23.490 & $\leq 0.001$ & 42.572 & $\leq 0.001$ & 19.371 & $\leq 0.001$ \\
\hline Robust LM (error) & 15.180 & $\leq 0.001$ & 4.173 & $\leq 0.050$ & 10.868 & $\leq 0.001$ \\
\hline
\end{tabular}

measurement method with reference to their ideas. In addition, the model of the above spatial process may have a problem in that the parameters cannot be identified [64].
The best way to solve this problem is to exclude the spatial autocorrelation error term, while the spatial Doberman model can solve the spatial autocorrelation problem of the 


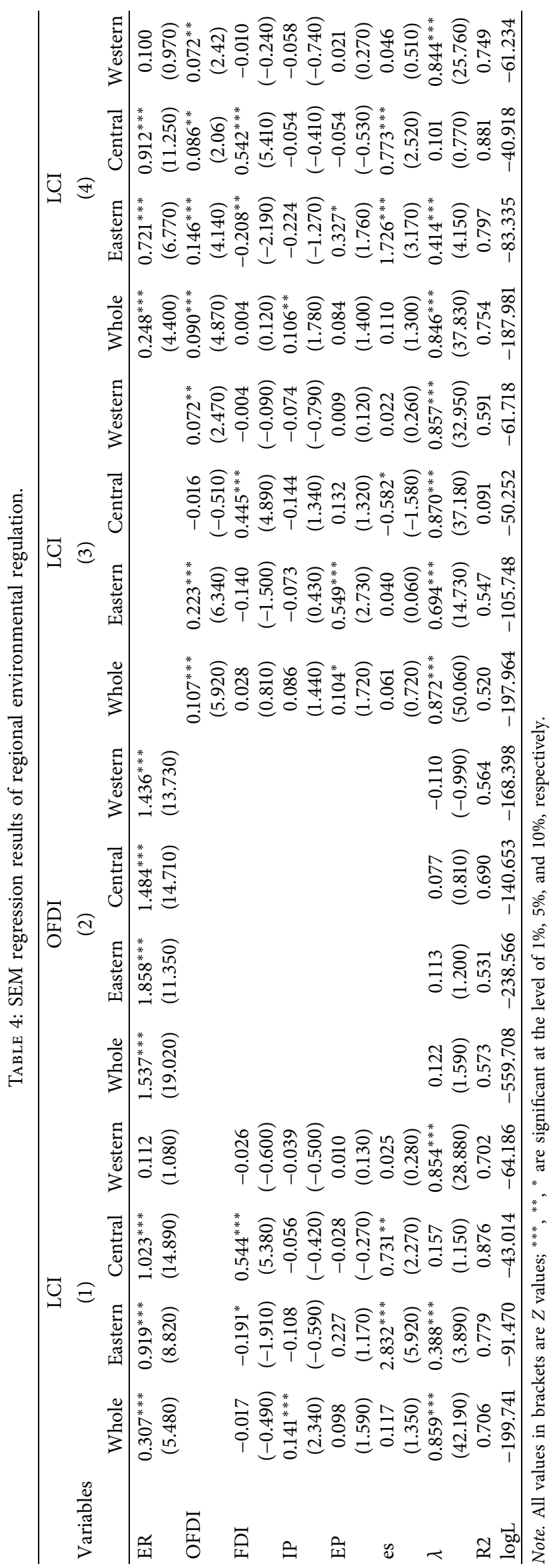


TABle 5: Robustness test.

\begin{tabular}{|c|c|c|c|c|c|c|c|c|}
\hline \multirow{2}{*}{ Variables } & \multicolumn{2}{|c|}{ LCI } & \multicolumn{2}{|c|}{ OFDI } & \multicolumn{2}{|c|}{ LCI } & \multicolumn{2}{|c|}{ LCI } \\
\hline & (1) & (2) & (1) & (2) & $(1)$ & $(2)$ & (1) & (2) \\
\hline ER & $\begin{array}{l}1.818^{* * *} \\
(43.320)\end{array}$ & $\begin{array}{c}0.333^{* * *} \\
(6.590)\end{array}$ & $\begin{array}{l}2.319^{* * *} \\
(24.750)\end{array}$ & $\begin{array}{c}0.895^{* * *} \\
(6.810)\end{array}$ & & & $\begin{array}{l}1.812^{* * *} \\
(30.660)\end{array}$ & $\begin{array}{c}0.232^{* * *} \\
(4.480)\end{array}$ \\
\hline OFDI & & & & & $\begin{array}{c}0.107^{* * *} \\
(5.920)\end{array}$ & $\begin{array}{c}0.136^{* * *} \\
(7.720)\end{array}$ & $\begin{array}{c}0.003 \\
(0.140)\end{array}$ & $\begin{array}{c}0.095^{* * *} \\
(5.220)\end{array}$ \\
\hline FDI & $\begin{array}{c}0.026 \\
(0.820)\end{array}$ & $\begin{array}{c}-0.019 \\
(-0.500)\end{array}$ & & & $\begin{array}{c}0.028 \\
(0.810)\end{array}$ & $\begin{array}{c}-0.047 \\
(-1.220)\end{array}$ & $\begin{array}{c}0.026 \\
(0.820)\end{array}$ & $\begin{array}{c}-0.033 \\
(-0.880)\end{array}$ \\
\hline IP & $\begin{array}{c}0.059 \\
(1.120)\end{array}$ & $\begin{array}{l}0.141^{* *} \\
(2.290)\end{array}$ & & & $\begin{array}{c}0.086 \\
(1.440)\end{array}$ & $\begin{array}{l}0.124^{* *} \\
(2.020)\end{array}$ & $\begin{array}{c}0.058 \\
(1.100)\end{array}$ & $\begin{array}{l}0.121^{* *} \\
(2.020)\end{array}$ \\
\hline EP & $\begin{array}{c}0.067 \\
(1.340)\end{array}$ & $\begin{array}{l}0.094^{*} \\
(1.600)\end{array}$ & & & $\begin{array}{l}0.104^{*} \\
(1.72)\end{array}$ & $\begin{array}{c}0.100^{*} \\
(1.70)\end{array}$ & $\begin{array}{l}0.067 \\
(1.33)\end{array}$ & $\begin{array}{c}0.081 \\
(1.420)\end{array}$ \\
\hline es & $\begin{array}{l}0.163^{* *} \\
(2.040)\end{array}$ & $\begin{array}{c}0.152 \\
(1.560)\end{array}$ & & & $\begin{array}{c}0.081 \\
(0.720)\end{array}$ & $\begin{array}{c}0.089 \\
(0.910)\end{array}$ & $\begin{array}{l}0.163^{* *} \\
(2.040)\end{array}$ & $\begin{array}{c}0.119 \\
(1.260)\end{array}$ \\
\hline$W * e r$ & & $\begin{array}{c}0.448^{* * *} \\
(5.540)\end{array}$ & & $\begin{array}{c}0.583^{* * *} \\
(3.440)\end{array}$ & & & & $\begin{array}{c}0.333^{* * * *} \\
(3.880)\end{array}$ \\
\hline$W^{*}$ ofdi & & & & & & $\begin{array}{c}0.195^{* * *} \\
(5.700)\end{array}$ & & $\begin{array}{c}0.080^{* *} \\
(2.110)\end{array}$ \\
\hline$W^{*} f d i$ & & $\begin{array}{c}-0.040 \\
(-0.550)\end{array}$ & & & & $\begin{array}{c}-0.236^{* * *} \\
(-3.110)\end{array}$ & & $\begin{array}{c}-0.146^{* *} \\
(-1.970)\end{array}$ \\
\hline$W^{*} i p$ & & $\begin{array}{c}-0.002 \\
(--0.010)\end{array}$ & & & & $\begin{array}{c}0.100 \\
(0.820)\end{array}$ & & $\begin{array}{c}0.059 \\
(0.500)\end{array}$ \\
\hline$W^{*} e p$ & & $\begin{array}{l}-0.076 \\
(0.840)\end{array}$ & & & & $\begin{array}{c}-0.047 \\
(-0.510)\end{array}$ & & $\begin{array}{c}-0.076 \\
(-0.860)\end{array}$ \\
\hline$W^{*} e s$ & & $\begin{array}{c}0.217 \\
(1.100)\end{array}$ & & & & $\begin{array}{c}0.043 \\
(0.220)\end{array}$ & & $\begin{array}{c}0.106 \\
(0.550)\end{array}$ \\
\hline$\rho$ & & $\begin{array}{c}0.444^{* * *} \\
(8.790)\end{array}$ & & $\begin{array}{l}0.145^{* *} \\
(2.090)\end{array}$ & & $\begin{array}{c}0.567^{* * * *} \\
(13.780)\end{array}$ & & $\begin{array}{c}0.392^{* * *} \\
(7.380)\end{array}$ \\
\hline$\lambda$ & $\begin{array}{c}0.330^{* * *} \\
(5.410)\end{array}$ & & $\begin{array}{c}0.139^{* *} \\
(1.960)\end{array}$ & & $\begin{array}{c}0.872^{* * *} \\
(50.060)\end{array}$ & & $\begin{array}{c}0.329^{* * *} \\
(5.400)\end{array}$ & \\
\hline $\begin{array}{l}R 2 \\
\log L\end{array}$ & $\begin{array}{c}0.903 \\
-80.528\end{array}$ & $\begin{array}{c}0.868 \\
-135.935\end{array}$ & $\begin{array}{c}0.661 \\
-510.297\end{array}$ & $\begin{array}{c}0.602 \\
-534.324\end{array}$ & $\begin{array}{c}0.520 \\
-197.964\end{array}$ & $\begin{array}{c}0.848 \\
-144.135\end{array}$ & $\begin{array}{c}0.903 \\
-80.518\end{array}$ & $\begin{array}{c}0.881 \\
-119.543\end{array}$ \\
\hline
\end{tabular}

Note. All values in brackets are $Z$ values; ${ }^{* * *},{ }^{* *},{ }^{*}$ are significant at the level of $1 \%, 5 \%$, and $10 \%$, respectively.

error term to a certain extent and provide unbiased coefficient estimation in most cases, because it contains the spatial lag explanatory variable and the interpreted variable [65].

As can be seen from Table 5, each model is stable and has no significant difference in coefficient value, which reflects the feasibility of the model and verifies the robustness of the model and data selection. It can be seen that environmental regulation and OFDI have significant spillover effects on low-carbon innovation, and environmental regulation also has spatial spillover effects on OFDI. It also shows that there is a spatial spillover effect in the path of environmental regulation affecting low-carbon innovation through the reverse technology spillover effect of OFDI.

\section{Discussion and Conclusions}

6.1. Discussion. This research article practices low-carbon innovation data along with panel data of pertinent control variables in thirty provinces of China from the year 2004 to 2017; besides that, it also uses a spatial econometric model to confer environmental regulation on OFDI, environmental regulation on low-carbon innovation; besides, the direct foreign impact of investment on low-carbon innovation and the intermediary effect of OFDI in the relationship amongst environmental regulation and lowcarbon innovation have altogether accepted the robustness test of data as well as the robustness test of measurement methods, also verifying the proposed environment regulatory assumptions about the spatial heterogeneity of lowcarbon innovation output.

6.2. Conclusion. Firstly, China's low-carbon innovation has obvious spatial agglomeration. Environmental regulations at the national and regional levels have significantly dissimilar endorsing effects on low-carbon innovation, clearly demonstrating that there is regional heterogeneity in this impact. Once again, the Porter hypothesis is verified, clearly proving that the improvement of environmental regulation level will stimulate some enterprises to carry out technological improvement and R\&D innovation activities $[66,67]$, promote the development of low-carbon innovation, and realize the "win-win" of environmental improvement and economic development.

Secondly, environmental regulation at the national and regional levels plays a significant role in promoting OFDI, demonstrating that environmental regulation has an important impact on international direct investment. More rigorous environmental regulations will force enterprises to 
avoid environmental regulation by transferring production processes to foreign countries in the process of OFDI, and the environmental regulation in different regions has different effects on low-carbon innovation. It can be perceived that the government has certain flaws in the formulation of environmental regulation strategies.

Thirdly, the growth of OFDI is favorable to promoting low-carbon innovation. Over OFDI, enterprises can acquire technical knowledge, form independent intellectual property rights, and realize reverse technology transfer, technology spillover, and technology diffusion, so as to enhance their own independent innovation ability. OFDI can also extend the duration of enterprise innovation in general, and OFDI has a significant reverse technology spillover effect. Through OFDI, enterprises can establish production relations with host countries, make strong use of resources and learn, and promote OFDI reverse technology spillover [68]. The impact of OFDI on low-carbon innovation varies significantly in different regions, which also shows that the development of Chinese enterprises is still seriously unbalanced.

Finally, with the strengthening of environmental regulations and the increase in OFDI, the development of lowcarbon innovation will be promoted. That is to say, the overall and regional environmental regulation can directly introduce foreign advanced technology through the channels of OFDI and reverse space technology spillover of OFDI to accelerate the development of low-carbon innovation. Furthermore, due to the differences in economic development and resource endowment between the eastern and the western regions, the direct and indirect impacts of environmental regulation on low-carbon innovation are regional heterogeneity. Additionally, over the Spatial Durbin Model, there are significant spatial spillover effects of environmental regulation and OFDI on low-carbon innovation, environmental regulation on OFDI, and the intermediary effects of OFDI on environmental regulation and low-carbon innovation.

6.3. Suggestions. Based on the above conclusions, the following suggestions can be put forward based on practice.

(1) When formulating environmental regulation policies, local governments should consider the bearing capacity of enterprises in different regions, increase the environmental regulation strategies for the eastern and central regions, give full play to the role of environmental regulation in promoting low-carbon innovation, and combine green subsidy soft policies to stimulate enterprises' low-carbon innovation power and promote the improvement of lowcarbon innovation capacity.

(2) Enterprise association, joint research and development, and sharing technology. For small- and medium-sized industrial enterprises, their R\&D funds and funds available for foreign investment are relatively small, so it is difficult to achieve low-carbon innovation by obtaining advanced technology from foreign countries. However, it can be combined with government subsidies for small- and medium-sized enterprises and solidarity between small- and medium-sized enterprises. Large enterprises in the alliance can drive small- and medium-sized enterprises and make use of the spatial agglomeration characteristics of enterprises coordinate with $\mathrm{R} \& \mathrm{D}$ and share technical achievements.

(3) Create a reasonable OFDI. The government should give full play to the role of market managers, provide financial support for the institutions of OFDI, especially increase the support for small- and mediumsized enterprises, strive to improve the learning ability of the domestic economy, establish links in the enterprises of OFDI and other domestic enterprises, and spread the income and learning ability gained by the enterprises of OFDI in foreign operations to the whole economy.

(4) The spatial spillover effect is significant and needs to be emphasized, so we should strengthen the coordinated development among regions and make full use of the spillover effect brought about by economic cooperation. We will vigorously promote the radiation-driven role of high- and low-carbon innovation areas.

6.4. Theoretical Contribution. Firstly, the technology innovation measurement method based on patent statistics measures low-carbon innovation using low-carbon innovation patent data. The analysis of foreign patent applications and layout is an important indicator of the current situation of a country's international technology competitiveness [69]. Over the statistical query of patent application data, the number of patent applications in a certain field is extracted, so as to observe the technological frontier development in this field. As of the most basic point of view, the low-carbon technology innovation index based on the number of patents can be used to measure the activity of low-carbon technology research in the macroeconomy, corresponding to the research resources in the theory of biased technological progress in low-carbon technology. There is the allocation level of the technology field; that is, the more patents there are, the higher R\&D investment and personnel allocation are. The allocation level of a certain field fundamentally determines the technological progress, economic output, and environmental performance of the department [70]. This paper uses the CPC-Y02 classification jointly issued by the EPO and USPTO in 2013, uses the INCOPAT patent retrieval system as the platform for patent retrieval, and surveys the classification of Y02. It can be found that it covers clean energy production, renewable energy power generation, and other completely clean technologies, as well as cogeneration, efficient combustion, and thermal utilization technologies, and other "grey technologies" aimed at improving the utilization efficiency of fossil energy. Therefore, patent technology in the Y02 classification can be equivalent to "low-carbon innovation."

Secondly, from a spatial perspective, the relationship model among the three is established to prove the 
intermediary role of OFDI between environmental regulation and low-carbon innovation, and the relationship among the three is regional heterogeneity. Environmental regulation will promote the improvement of regional innovation capacity [71], and the use and effects of the same policy tools in different countries and regions are different. On the other hand, environmental regulation plays a decisive role in FDI [72]. FDI can not only significantly improve the technological efficiency of enterprises [73], but also enhance lowcarbon innovation capacity through its reverse technology spillover effect [74]. Environmental regulation can speed up the development of low-carbon innovation through the direct introduction of foreign advanced technology through the channels of OFDI and the reverse technology spillover of OFDI. Because of the differences in economic development and resource endowment between the eastern and the western regions, there is regional heterogeneity in the direct and indirect impacts of environmental regulation on lowcarbon innovation.

Finally, the Spatial Durbin Model was used to verify the robustness of the model. At the same time, the spatial spillover effect of environmental regulation and OFDI on low-carbon innovation and the spatial spillover effect of environmental regulation on OFDI were also verified. Specifically, the relatively strict environmental regulation policies in the region will enable local enterprises to take the lead in low-carbon innovation, thus seizing the market and threatening the market share of neighboring regions. To maintain their market, neighboring regions will increase their own innovation investment and promote the development of lowcarbon innovation. At the same time, the strengthening of local environmental regulations makes local innovation ability relatively high. Enterprises in the surrounding areas will also consider obtaining technology spillover through OFDI to improve their low-carbon innovation ability.

\section{Data Availability}

The data used to support the findings of this study are available from the corresponding author upon request.

\section{Disclosure}

Chaojun Yang and Wenke Yang are co-first authors

\section{Conflicts of Interest}

The authors declare that they have no conflicts of interest.

\section{Authors' Contributions}

Chaojun Yang and Wenke Yang contributed equally to this work. Liju Liu contributed to data collection and image processing. Ahmed Tanveer performed English proofreading.

\section{Acknowledgments}

The authors are grateful for the financial support from the National Natural Science Foundation of China (71964019,
71502074), the Scientific Research Fund Project of Yunnan Education Department (2019Y0042), the Fundamental Research Funds for the Central Universities (3214002104D), the Postgraduate Research and Practice Innovation Program of Jiangsu Province (KYCX20_0165), and the Applied Basic Research Program of Yunnan Province (KKS0202008031).

\section{References}

[1] C. Ljungwall and P. G. Tingvall, "Is China different? A metaanalysis of the growth-enhancing effect from $\mathrm{R} \& \mathrm{D}$ spending in China," China Economic Review, vol. 36, pp. 272-278, 2015.

[2] P. Lanoie, M. Patry, and R. Lajeunesse, "Environmental regulation and productivity: testing the porter hypothesis," Journal of Productivity Analysis, vol. 30, no. 2, pp. 121-128, 2008.

[3] L. L. Guo, Y. Qu, and M.-L. Tseng, "The interaction effects of environmental regulation and technological innovation on regional green growth performance," Journal of Cleaner Production, vol. 162, pp. 894-902, 2017.

[4] B. Dong, J. Gong, and X. Zhao, "FDI and environmental regulation: pollution haven or a race to the top?" Journal of Regulatory Economics, vol. 41, no. 2, pp. 216-237, 2012.

[5] Y. Feng, X. Wang, W. Du, H. Wu, and J. Wang, "Effects of environmental regulation and FDI on urban innovation in China: a spatial Durbin econometric analysis," Journal of Cleaner Production, vol. 235, pp. 210-224, 2019.

[6] C.-T. Hsieh and P. J. Klenow, "Misallocation and manufacturing TFP in China and India," Quarterly Journal of Economics, vol. 124, no. 4, pp. 1403-1448, 2009.

[7] P. Piperopoulos, J. Wu, C. Wang, and F. D. I. Outward, "Outward FDI, location choices and innovation performance of emerging market enterprises," Research Policy, vol. 47, no. 1, pp. 232-240, 2018.

[8] J. Yin, S. Wang, and L. Gong, "The effects of factor market distortion and technical innovation on China's electricity consumption," Journal of Cleaner Production, vol. 188, pp. 195-202, 2018.

[9] G.-B. Bi, W. Song, P. Zhou, and L. Liang, "Does environmental regulation affect energy efficiency in China's thermal power generation? empirical evidence from a slacks-based DEA model," Energy Policy, vol. 66, no. 3, pp. 537-546, 2014.

[10] X. Liao and X. Shi, "Public appeal, environmental regulation and green investment: evidence from China," Energy Policy, vol. 119, pp. 554-562, 2018.

[11] A. M. Leiter, A. Parolini, and H. Winner, "Environmental regulation and investment: evidence from European industry data," Ecological Economics, vol. 70, no. 4, pp. 759-770, 2011.

[12] Y. Ge, Y. Hu, and S. Ren, "Environmental regulation and foreign direct investment: evidence from China's eleventh and twelfth five-year plans," Sustainability, vol. 12, 2020.

[13] L. Huang and Z. Lei, "How environmental regulation affect corporate green investment: evidence from China," Journal of Cleaner Production, vol. 279, Article ID 123560, 2021.

[14] Y. Cao and J. You, "The contribution of environmental regulation to technological innovation and quality competitiveness: an empirical study based on chinese manufacturing enterprises," Chinese Management Studies, vol. 11, no. 1, pp. 51-71, 2017.

[15] X. Zhao, Y. Zhao, S. Zeng, and S. Zhang, "Corporate behavior and competitiveness: impact of environmental regulation on Chinese firms," Journal of Cleaner Production, vol. 86, pp. 311-322, 2015. 
[16] UNCTAD, World Investment Report 2017: Investment and the Digital Economy, United Nation Publication, Geneva, Switzerland, 2017.

[17] F. Li and C. Yu, "OFDI and home country structural upgrading: does spatial difference exist in China?" Emerging Markets Finance and Trade, vol. 56, no. 7, pp. 1532-1546, 2020.

[18] V. Z. Chen, J. Li, and D. M. Shapiro, "International reverse spillover effects on parent firms: evidences from emergingmarket MNEs in developed markets," European Management Journal, vol. 30, no. 3, pp. 204-218, 2012.

[19] T. Yang, Q. Dong, Q. Du, M. Du, R. Dong, and M. Chen, "Carbon dioxide emissions and Chinese OFDI: from the perspective of carbon neutrality targets and environmental management of home country," Journal of Environmental Management, vol. 295, Article ID 113120, 2021.

[20] Q. Khachoo, R. Sharma, and M. Dhanora, "Does proximity to the frontier facilitate FDI-spawned spillovers on innovation and productivity?" Journal of Economics and Business, vol. 97, 2018.

[21] G. V. G. Stevens and R. E. Lipsey, "Interactions between domestic and foreign investment," Journal of International Money and Finance, vol. 11, no. 1, pp. 40-62, 1992.

[22] S. Goldbach, A. J. Nagengast, E. Steinmüller, and G. Wamser, "The effect of investing abroad on investment at home: on the role of technology, tax savings, and internal capital markets," Journal of International Economics, vol. 116, no. 1, pp. 58-73, 2019.

[23] B. Ni and H. Kato, "Do vertical spillovers differ by investors' productivity? theory and evidence from Vietnam," Review of Development Economics, vol. 24, no. 3, pp. 1046-1072, 2020.

[24] Y. Kang and F. Jiang, "FDI location choice of Chinese multinationals in East and Southeast Asia: traditional economic factors and institutional perspective," Journal of World Business, vol. 47, no. 1, pp. 45-53, 2012.

[25] X. Ren and S. Yang, "Empirical study on location choice of Chinese OFDI," China Economic Review, vol. 61, Article ID 101428, 2020.

[26] A. Phene and P. Almeida, "Innovation in multinational subsidiaries: the role of knowledge assimilation and subsidiary capabilities," Journal of International Business Studies, vol. 39, no. 5, pp. 901-919, 2008.

[27] Y. Su, X. Jiang, and Z. Lin, "Simulation and relationship strength: characteristics of knowledge flows among subjects in a regional innovation system," Science, Technology and Society, 2021.

[28] Y. Jiang, D. Asante, J. Zhang, and M. Cao, "The effects of environmental factors on low-carbon innovation strategy: a study of the executive environmental leadership in China," Journal of Cleaner Production, vol. 266, Article ID 121998, 2020.

[29] P. Ekins, "Eco-innovation for environmental sustainability: concepts, progress and policies," International Economics and Economic Policy, vol. 7, no. 2-3, pp. 267-290, 2010.

[30] A. Kolk and J. Pinkse, "Business responses to climate change: identifying emergent strategies," California Management Review, vol. 47, no. 3, pp. 6-20, 2005.

[31] C. Díaz-García, Á. González-Moreno, and F. J. Sáez-Martínez, "Eco-innovation: insights from a literature review," Innovation, vol. 17, no. 1, pp. 6-23, 2015.

[32] R. Raven, F. Kern, A. Smith, S. Jacobsson, and B. Verhees, "The politics of innovation spaces for low-carbon energy: introduction to the special issue," Environmental Innovation and Societal Transitions, vol. 18, pp. 101-110, 2016.
[33] T. Altenburg and A. Pegels, "Sustainability-oriented innovation systems - managing the green transformation," Innovation and development, vol. 2, no. 1, pp. 5-22, 2012.

[34] D. Tyfield, A. Ely, and S. Geall, "Low carbon innovation in China: from overlooked opportunities and challenges to transitions in power relations and practices," Sustainable Development, vol. 23, no. 4, pp. 206-216, 2015.

[35] E. Uyarra, P. Shapira, and A. Harding, "Low carbon innovation and enterprise growth in the UK: challenges of a placeblind policy mix," Technological Forecasting and Social Change, vol. 103, pp. 264-272, 2016.

[36] R. Ramanathan, Q. He, A. Black, A. Ghobadian, and D. Gallear, "Environmental regulations, innovation and firm performance: a revisit of the Porter hypothesis," Journal of Cleaner Production, vol. 155, pp. 79-92, 2017.

[37] J. Dou and X. Han, "How does the industry mobility affect pollution industry transfer in China: empirical test on Pollution Haven Hypothesis and Porter Hypothesis," Journal of Cleaner Production, vol. 217, pp. 105-115, 2019.

[38] Y. Wang, X. Sun, and X. Guo, "Environmental regulation and green productivity growth: empirical evidence on the Porter Hypothesis from OECD industrial sectors," Energy Policy, vol. 132, pp. 611-619, 2019.

[39] M. Wagner, "The role and effectiveness of environmental and social regulations in creating innovation offsets and enhancing firm competitiveness," in The Dynamics of Environmental and Economic Systems, V. Ostantini and M. Mazzanti, Eds., pp. 83-95, Springer, Dordrecht, Netherlands, 2012.

[40] H. Wang, Z. Chen, X. Wu, and X. Nie, "Can a carbon trading system promote the transformation of a low-carbon economy under the framework of the porter hypothesis? -Empirical analysis based on the PSM-DID method," Energy Policy, vol. 129, pp. 930-938, 2019.

[41] J. Wu, C. Wang, J. Hong, P. Piperopoulos, and S. Zhuo, "Internationalization and innovation performance of emerging market enterprises: the role of host-country institutional development," Journal of World Business, vol. 51, no. 2, pp. 251-263, 2016.

[42] O. R. Malik and M. Kotabe, "Dynamic capabilities, government policies, and performance in firms from emerging economies: evidence from India and Pakistan," Journal of Management Studies, vol. 46, no. 3, pp. 421-450, 2009.

[43] P. Fan, "Innovation, globalization, and catch-up of latecomers: cases of Chinese telecom firms," Environment and Planning A: Economy and Space, vol. 43, no. 4, pp. 830-849, 2011.

[44] Y. Yadong Luo, J. Jinyun Sun, and S. Lu Wang, "Emerging economy copycats: capability, environment, and strategy," Academy of Management Perspectives, vol. 25, no. 2, pp. 3756, 2011.

[45] W. Yang, Q. Ma, M. Tian, L. Wang, and J. He, "The staged financing selection mechanism for government to maximize the green benefits of start-ups," Mathematical Problems in Engineering, vol. 2021, Article ID 9921355, 13 pages, 2021.

[46] D. Xin and Y. Zhang, "Threshold effect of OFDI on China's provincial environmental pollution," Journal of Cleaner Production, vol. 258, p. 120608, 2020.

[47] N. Agarwal, C. Milner, and A. Riaño, "Credit constraints and spillovers from foreign firms in China," Journal of Banking \& Finance, vol. 48, pp. 261-275, 2014.

[48] M. A. Cole, "Trade, the pollution haven hypothesis and the environmental Kuznets curve: examining the linkages," Ecological Economics, vol. 48, no. 1, pp. 71-81, 2004. 
[49] B. R. Copeland and M. S. Taylor, "North-South trade and the environment," Quarterly Journal of Economics, vol. 109, no. 3, pp. 755-787, 1994.

[50] S. A. Javeed, R. Latief, and L. Lefen, "An analysis of relationship between environmental regulations and firm performance with moderating effects of product market competition: empirical evidence from Pakistan," Journal of Cleaner Production, vol. 254, Article ID 120197, 2020.

[51] C. Atici, "Carbon emissions, trade liberalization, and the Japan-ASEAN interaction: a group-wise examination," Journal of the Japanese and International Economies, vol. 26, no. 1, pp. 167-178, 2012.

[52] V. Costantini, F. Crespi, and A. Palma, "Characterizing the policy mix and its impact on eco-innovation: a patent analysis of energy-efficient technologies," Research Policy, vol. 46, no. 4, pp. 799-819, 2017.

[53] N. Johnstone, I. Haščič, and D. Popp, "Renewable energy policies and technological innovation: evidence based on patent counts," Environmental and Resource Economics, vol. 45, no. 1, pp. 133-155, 2010.

[54] L. Zhang, Q. Wang, and M. Zhang, "Environmental regulation and $\mathrm{CO}_{2}$ emissions: based on strategic interaction of environmental governance," Ecological Complexity, vol. 45, Article ID 100893, 2021.

[55] S. Li, S. Chu, and C. Shen, "Local government competition, environmental regulation and regional ecological efficiency," Journal of World Economy, vol. 37, no. 04, pp. 88-110, 2014.

[56] P. G. Fredriksson and D. L. Millimet, "Strategic interaction and the determination of environmental policy across U.S. States," Journal of Urban Economics, vol. 51, no. 1, pp. 101-122, 2002.

[57] R. Hashmi and K. Alam, "Dynamic relationship among environmental regulation, innovation, $\mathrm{CO} 2$ emissions, population, and economic growth in OECD countries: a panel investigation," Journal of Cleaner Production, vol. 231, pp. 1100-1109, 2019.

[58] X. Liu, K. Lin, and L. Wang, "Stochastic evolutionary game analysis of e-waste recycling in environmental regulation from the perspective of dual governance system," Journal of Cleaner Production, vol. 319, Article ID 128685, 2021.

[59] M. Zhang, X. Liu, Y. Ding, and W. Wang, "How does environmental regulation affect haze pollution governance?-An empirical test based on Chinese provincial panel data," The Science of the Total Environment, vol. 695, p. 133905, 2019.

[60] J. Ederington and J. Minier, "Is environmental policy a secondary trade barrier? An empirical analysis," Canadian Journal of Economics/Revue Canadienne d'Economique, vol. 36, no. 1, pp. 137-154, 2003.

[61] Y. Su and Y.-q. Yu, "Spatial agglomeration of new energy industries on the performance of regional pollution control through spatial econometric analysis," The Science of the Total Environment, vol. 704, p. 135261, 2020.

[62] W. Antweiler, B. R. Copeland, and M. S. Taylor, "Is free trade good for the environment?" The American Economic Review, vol. 91, no. 4, pp. 877-908, 2001.

[63] L. Anselin, R. J. G. M. Florax, and S. J. Rey, "Econometrics for spatial models: recent advances," in Advances in Spatial Econometrics, pp. 1-25, Springer, Berlin, Germany, 2004.

[64] F. Charles, "Manski. "Identification of endogenous social effects: the reflection problem," The Review of Economic Studies, vol. 60, pp. 531-542, 1993.

[65] J. LeSage and R. K. Pace, Introduction to Spatial Econometrics, CRC Press, Boca Raton, FL, USA, 2009.
[66] M. Greenstone, J. A. List, and C. Syverson, "The effects of environmental regulation on the competitiveness of US manufacturing (No. w18392)," National Bureau of Economic Research, p. 18392, 2012.

[67] R. Yana, G. Marzio, and V. Elena, "Environmental regulation and competitiveness: empirical evidence on the Porter Hypothesis from European manufacturing sectors," Energy Policy, vol. 83, 2015.

[68] J. A. Mathews, "Dragon multinationals: new players in 21st century globalization," Asia Pacific Journal of Management, vol. 23, no. 1, pp. 5-27, 2006.

[69] M. Grimaldi, L. Cricelli, M. Di Giovanni, and F. Rogo, "The patent portfolio value analysis: a new framework to leverage patent information for strategic technology planning," Technological Forecasting and Social Change, vol. 94, pp. 286-302, 2015.

[70] D. Acemoglu, P. Aghion, L. Bursztyn, and D. Hemous, "The environment and directed technical change," The American Economic Review, vol. 102, no. 1, pp. 131-166, 2012.

[71] C.-H. Yang, Y.-H. Tseng, and C.-P. Chen, "Environmental regulations, induced $\mathrm{R} \& \mathrm{D}$, and productivity: evidence from Taiwan's manufacturing industries," Resource and Energy Economics, vol. 34, no. 4, pp. 514-532, 2012.

[72] I. Kolstad and A. Wiig, "What determines Chinese outward FDI?" Journal of World Business, vol. 47, no. 1, pp. 26-34, 2012.

[73] S.-F. Yang, K.-M. Chen, and T.-H. Huang, "Outward foreign direct investment and technical efficiency: evidence from Taiwan's manufacturing firms," Journal of Asian Economics, vol. 27, pp. 7-17, 2013.

[74] J. Li, R. Strange, L. Ning, and D. Sutherland, "Outward foreign direct investment and domestic innovation performance: evidence from China," International Business Review, vol. 25, no. 5, pp. 1010-1019, 2016. 